\title{
Human life cycle and the Beginning of Life: An Islamic Perspective
}

\section{KARIM HASSANEIN ISMAIL ABD-EL-MAEBOUD, M.D.}

Professor of OB/GYN, Ain Shams Faculty of Medicine, Cairo, Egypt

2 Mobarak St., off Asmaa Fahmy, Ard El-Golf, Heliopolis, Cairo, Egypt.

\section{Correspondence:}

Karim Hassanein Ismai

Abd-El-Maeboud, M.D.

Professor of OB/GYN Ain Shams Faculty

of Medicine Cairo, Egypt

2 Mobarak St., off Asmaa Fahmy

Ard El-Golf, Heliopolis

Cairo, Egypt

E-mail: kabdelmaeboud@yahoo.com

Telephone: (00202) 24140680 / 24140675

Key words: Islam, Qur'an, human life, start of life, birth, viability, implatation, fertilization, genetic uniqueness

Received December 20, 2007

\section{Abstract}

Although the definition of the beginning of life is rather difficult, Islamic teachings clarify that ensoulment-occurring after 40 or 120 days from conception - is a crucial point. However, Islam confers respect and protection earlier to this point. The human life cycle is depicted in the Holy Qur'an demonstrating that human life is a continuum. Along this cycle, certain hallmark points deserve consideration as they have been referred to in the Holy Qur'an. These include: birth, the age of viability, ensoulment and quickening, implantation, and fertilization with genetic uniqueness. Considering basic human rights as decreed in Islam, there is an escalation in gaining these rights from fertilization up to delivery. Although this escalation clarifies the absence of full human rights of a developing fetus till being viable and born alive, it does not negate one basic right, "the right to life", i.e. to be protected as a potential human being with eventual full human rights. As shown here, the close matching between Qur'an, the word of Allah, and science, the deeds of Allah, poses no major conflicts in defining the start of human life. The consensus is that from the moment a zygote is formed, it deserves a unanimously recognized degree of respect. The occurrence of ensoulment after 40 days should not be taken as a prelude to justify unaccepted tampering with on a man-to-be developing zygote.

\section{INTRODUCTION}

Tnterest in human development has always been widespread largely 1 because of curiosity about the subject and a desire to improve the quality of human life. Muslims believe that God is the Creator of life and life is a gift from Him. The human race is the noblest race as God decreed: »We have honoured the sons of Adam; provided them with transport on land and sea; given them for sustenance things good and pure; and conferred on them special favours, above a great part of Our Creation.« (17:70) $(1,2)$. In Islam, the human life is sacred, and should be protected and not taken away except upon indications singled out and specified by the law: »On that account: We ordained for the Children of Israel that if anyone slew a person - unless it be for murder or for spreading mischief in the land - it would be as if he slew the whole people: and if any one saved a life, it would be as if he saved the life of the whole people.« $(32: 5)(1,2)$. Many facts concerning early human development are mentioned in the Holy Qur'an and Hadith (the traditions of the Prophet Mohammad - peace be upon him, pbuh - including his sayings, his practice and acknowledgements as collected by specialists in Hadith) (3-5). Commentators or interpreters of the Holy Qur'an have tried to understand these facts (6-8). 
The definition of the beginning of life has lately become a hot ethical topic, not only in relation to abortion but also concerning assisted reproduction techniques, embryo research, stem cell therapy and cloning. Many emerging issues have arisen from these technological advances that led many people to try to identify how we can deal with such situations (9-11). The definition - and subsequently timing - of the start of life still poses a serious point of controversy, as ahead of it the case can not be classified as murder (12).

The order of sources of fiqh (jurisprudence in the Islamic tradition) - used in the process of establishing a legal or ethical - position are known to Qur'an, Sunnah (the Prophet's actions and precepts), ijma (general agreement), qiyas (analogical deduction), istihsan (juristic preference), and maslahah (benefit or interest). These have been recently excellently reviewed with protection of life, religion, intellect, lineage, and property being considered maslahah for any person (10). Since every person started as a fetus, Islam confers respect and protection on the fetus since the time it is there. Various legal rulings were decreed by Islam to safeguard the wellbeing and healthy development of the fetus. It made it an obligatory duty on the father to provide for the pregnancy and answer its financial needs even if divorce or separation or other circumstances have severed the relations with its mother. It is for the sake and welfare of the fetus that the pregnant woman is exempted from the obligatory fast of the month of Ramadan. If a woman commits a crime the punishment of which is death and is proven to be pregnant, then the execution of the punishment shall be postponed until she gives birth to her baby and completes its breast feeding until weaned. This is a straightforward acknowledgement of the right to life of the fetus, being applied even if the pregnancy was illegitimate, emphasizing that the fetus conceived out-of-wedlock also has the right to live. The fetus has the right to be related to its father without confusion of paternity. If its mother is a divorcee or a widow then she should not marry until the fetus is born so as to keep the genealogy clear. If a man dies while his wife is pregnant, then the rules of inheritance recognize the fetus as an inheritor if born alive. Islam prescribes punitive measures for assaults on the fetus resulting in miscarriage (12).

\section{HUMAN CREATION IN THE HOLY QUR'AN}

Three embryological terms for early human development are presented in the Holy Qur'an and substantiated by Hadith; these are 'Nutfah', 'Alaqah', and 'Mudghah'. The first term, 'Nutfah', refers to the gametes (male and female) and the zygote, however the latter comes in a special term »a nutfah amshaj $(76: 1,2)(1,2)$ in the context of genetic uniqueness. The second term, 'Alaqah', refers to zygote and its subsequent developmental stages required for implantation. The third term, 'Mudghah', refers to the somite stage $(13,14)$.

The Holy Qur'an almost always refers to the similarities between human and plant creation. In the Holy
Qur'an it is stated: »Your wives are as a tilth unto you: so approach your tilth when or how you will« $(2: 223)$ (1, $2)$. The simile in the verse makes the female genitalia, the copulation, the 'nutfah', and the ensuing child similar to a tilth, plowing, a seed, and a plant; respectively $(6,7,12$, 15). The human being is formed by the union of a pair of gametes; i.e. two 'nutfahs', a male gamete (sperm) and female gamete (ovum). In Hadith, the Prophet- pbuh said 'O Jew! Man is created from both man's 'nutfah' and female's 'nutfah'.' (5). The gametes are released in fluid environment: »Was he not a 'nutfah' out of semen 'tomna' (ejaculated) ? « $(75: 37)(1,2)$. This verse clearly states that a 'nutfah' or sperm is a part of semen that constitutes also seminal plasma or water in which these pearls are found. Similarly, a female 'nutfah' or ovum swims in follicular fluid. In Hadith it is stated that 'not from the whole water is the offspring created' (4). The mode of release of this water is peculiar: $» \mathrm{He}$ is created from water gushing forth * Proceeding from between the backbone and the ribs « $(86: 6,7)(1,2)$. Once the release of gamete is inevitable in a man or a woman, the water is "gushing forth " unintentionally on ejaculation or ovulation, respectively (16). The statement in the following verse »Proceeding from between the backbone and the ribs « $(86: 7)(1,2)$ refers to the embryological origin of the gonads $(8,12$, 16-18). This water jets out of the sex glands that originally develop in both sexes from the primitive gonads lying bilaterally on the upper posterior abdominal wall in-between the spine and lower ribs $(15,18,19)$. The weakness of this water - both man's and woman's waters - from which man is created is depicted in the verses: »He Who has made everything which $\mathrm{He}$ has created Most Good: He began the creation of man with (nothing more than) clay * And made his progeny from a quintessence ('sulalah') of the nature of weak ('maheen') water" $(32: 7,8)$. »Have We not created you from weak ('maheen') water? * Which We placed in a place of rest, firmly fixed ('quarar makeen') * For a predetermined destiny * For We do determine (destiny); for We are the Best to do (make it happen).«(77:20-23) (1, 2). Recent scientific facts demonstrate how this weakness applies to both sperms and oocytes, especially the latter, necessitating special careful handling and environmental conditions during in vitro manipulations in various assisted reproduction techniques (20). So, Allah dictated that man is to be created from a weak 'nutfah' and this clarifies the need for storage in a special reservoir, the sex gland - »a place of rest, firmly fixed " or 'quarar makeen' - in the human body. Inside this reservoir, it is safely kept until it subsequently fulfills its predetermined destiny as planned by Allah. This special "place of rest« or 'quarar makeen' is mentioned also in another context in the Holy Qur'an $(23: 12,13)(1,2)$. The Arabic word 'quarar' means a place of earth where water is lodged (21). The adjective 'make$e n$ ' implies that in the 'quarar' the 'nutfah' is lodged or settled restful, being safely preserved to fulfill its destiny (13). Mankind is virtually earth walking and scattering over earth $(20: 55 ; 30: 20)(1,2)$. Being just a living earth, humans constitute a source of 'water' or 'nutfah' that is destined to jet and subsequently evolve into a plant, in 
accordance with the verse $(86: 6)(1,2)$. Actually, the timing of jetting of any 'nutfah', if any, and its destiny is predetermined by Allah $(77: 22-23)(1,2)$. So, descendant lineages are predetermined (13). Germination is the sprouting of a seed, spore, or other reproductive body, usually after a period of dormancy (22). This term is used in Holy Qur'an to denote implantation: »'And Allah has caused you to germinate from the earth into plants' « (71:17) $(1,2)$. It is interesting that man came to acknowledge the similarity of this stage in human development to plant development. Implant (L. im-, in, + planto, pp. -atus, to plan) means to graft or insert. In obstetrics, implantation means attachment of fertilized ovum (blastocyst) to the endometrium and its subsequent embedding in the compact layer (23). Implantation is an integrated series of both independent and mutually dependent events, which culminate in embedding of the embryo within the stroma of the uterine endometrium and the establishment of a placental interface between embryonic tissue and maternal vascular channels $(15,18,19,24-27)$. In fact, the events giving rise to a successfully implanted embryo may be simply analyzed in terms of soil (maternal tissue) and seed (fertilized oocyte) (28). The close similarity between implantation and germination is evident on considering removal of the covering, orientation of the embryo, and the development of a system of trophic processes $(15,18,19,22,24-27)$. Overall, the similes in the verses make the female genitalia, the copulation, the 'nutfah', the gonad, the womb, implantation, and the ensuing child similar to a tilth, plowing, a seed, a spring, earth, germination and a plant.

\section{HUMAN LIFE CYCLE AND THE BEGINNING OF HUMAN LIFE}

The three terms, 'Nutfah', 'Alaqah', and 'Mudghah', come in the context of a single verse $(22: 5)(1,2)$ depicting human life cycle. Life is a continuum and a life cycle is a cycle demonstrating stages or phases through which the organism must pass in order to procreate, with a generation following the other, i.e. it demonstrates how life of a certain organism, as a species, continues (Figure 1). The initial call » $\mathbf{O}$ mankind! « is addressing all people; "If you have doubt about the Resurrection «, the issue discussed; and Allah drives to mankind only one proof, our creation; »We have created you «. The absolute start of creation was »out of dust «, followed by life cycle comprising the already-mentioned three phases »then out of a 'nutfah', then out of an 'alaqah', then out of a 'mudghah', partly formed and partly unformed « $(13,29)$. These phases correspond to the three phases of animal life cycle - gamete, zygote, and multicellular diploid - being depicted (also in singular forms) by man only by the start of the twentieth century (30). Man is virtually $»$ a mudghah comprising two parts with different destinies, one part 'formed' i.e. fully and evidently created forming man's own unique personal identity, and the other 'unformed' i.e. not formed or evidently created yet. That is the germ cells; the raw material for reproduction. Later on, it is to

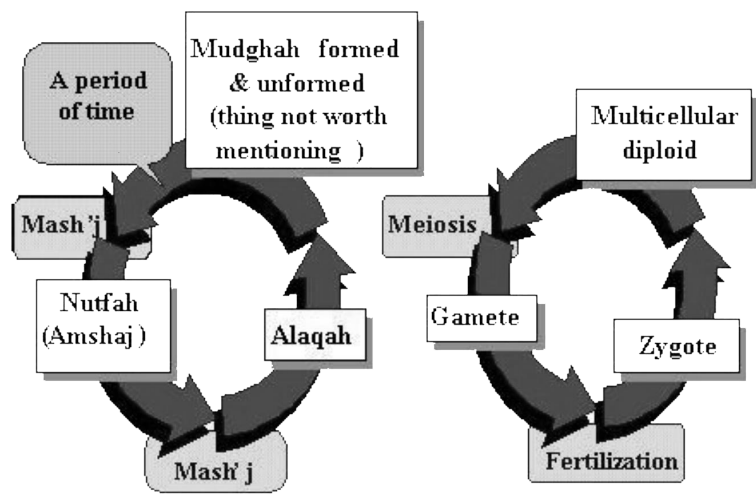

A) The HolyQur'an

B) Scientific Facts

Figure 1. Human life cycle: A) In Holy Qur'an: based on interpretation of verses 22:5 and 76:1,2 (see text); B) In modern science (Keeton WT 1976 Biologic Science. New York, Norton, p 579 Cited by (30)).

be formed into "mudghah" (the offspring) by passing through "nutfah" and "alaqah" stages $(13,29)$.

In biologic sense, life never stops since it is a continuous process. To ask when life begins is the wrong question; biologically the correct answer would be, 'diploid life' begins as a result of fertilization, and, 'haploid life' begins as a result of meiosis (30). Though being so stringent, this concept concerns life as a vital process on cellular or species' level and not on individual's level, since 'having a life' is distinct from 'being alive' (30). In traditional embryology, the terms embryo and fetus have been used $(15,19)$. Recent advances in embryology have complicated that simple delineation with introduction of the term pre-embryo denoting the developmental phases over the first two weeks starting by fertilization $(30,31)$. In fact, human life is a continuum as already depicted in the Holy Qur'an and later in biology, within which are milestone points - birth of a newborn, viability, ensoulment, quickening, implantation and fertilization - that may be claimed as the beginning of human life (Figure 2). With such a spectrum, the beginning of human life will be always seen differently by different individuals, groups, cultures, and religious faiths, each being influenced by their convictions concerning the subject $(12,30$,

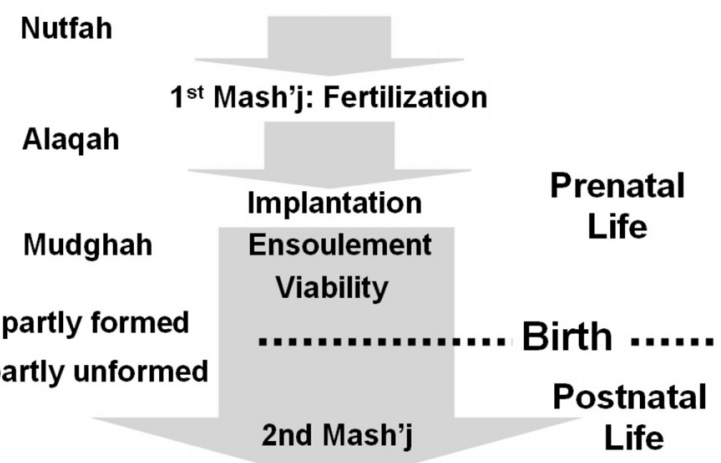

Figure 2. Human life cycle: Milestone points along the continuum. 
32). Generally, the definition of a transition point usually poses difficulties, and this has been recently applied to two vital transition points in human life on individual level; its beginning and its end. A biologic concept might help here, is that 'having a life' is distinct from 'being alive' (30). One Islamic concept »Doubt does not defy certainty « is also of help. In case of a living person, undisputable evidences must be supplied to document his death. Likewise, in case of gametes, undisputable evidences must be supplied to document a point at which individual's life starts. In considering the various suggested points, it is beneficial to consider human status in relation to changes of human rights - already discussed across these points.

\section{Birth}

In the second part of the verse addressing human life cycle as a species $(22: 5)(1,2)$ and immediately following it, the phases describing individual's life cycle on earth are mentioned: »And We cause whom We will to rest in the wombs for an appointed term «, intra-uterine life; »then do We bring you out as babes «, infancy and childhood; »then (foster you) that ye may reach your age of full strength «, adulthood; »and some of you are called to die«, death; »and some are sent back to the feeblest old age «, or aging before death. Despite the fact that Allah is the real subject of all verbs in this part, it is interesting to notice that only the first three verbs - »cause to rest « "will « and »bring out « - were directly related to Him. As life cycle could implicate autonomous reproduction, the first two verbs are mentioned to negate the idea of uncontrolled random chance of further development. Putting into consideration that the cornerstone of the verse is the argument about creation, one might see the wisdom in this formulation. The three verbs are directly related to creation of a man till he is delivered and attains a full identity. So, they are directly related to Allah. The other three verbs are not related to the process of creation itself. So, they are not directly related to Him. If man believes that Allah is the creator, he would automatically believe in what are seemingly less evident proofs of His ominous power (13). This clearly implies that full creation is attained only on delivery, and that previous points are to be considered less complete. Failed to born alive deprives the fetus from inheritance, an accredited basic right offered to a living neonate in Islam. Considering this, it is evidently clear that the humanity of the undelivered fetus is less than norm (e.g. his alive and already-delivered twin).

\section{Viability}

That the shortest duration of a pregnancy producing a viable fetus is 6 months, has been known as an Islamic fact based on interpretation of three verses (2:233, 31:14, 46:15) in the Holy Qur'an. Scientifically, the starting point of any pregnancy is at fertilization. The endpoint is when the fetus has reached a developmental stage enabling independent existence, i.e. survival after birth without outside help, including intensive neonatal care facilities. The time unit for pregnancy duration in the verses is the lunar month (29.5 days). Accordingly, viability is established at 177 days ( 25 weeks +2 days) post-ovulation or post-fertilization. Based on recent studies, many centers have recently reset the age of viability at 25 weeks ovulation or fertilization age. For more than 14 centuries, Islamic teachings have dictated that viability is correlated to pregnancy duration; a parameter only recently proved to be more accurate than fetal weight (33). The close matching of Islamic facts, depicting this natural law, and recent solid scientific facts is clearly apparent. A fetus, at 22-25 weeks (fertilization age), may die within a few days if born prematurely, mainly because its respiratory system is still immature $(15,34-36)$. At 24 weeks, the type II alveolar epithelial cells begin to secrete surfactant $(15,36)$. By 25 to 28 weeks (fertilization age), sufficient terminal sacs are present to permit survival of a prematurely born infant (15). A fertilization age of 25 weeks corresponds to a gestational age of 27 weeks set by others as a cutoff for survival (18). It might be argued that viability does not transform the nature of the fetus by turning the non-human being into a human being. Viability is a measure of the sophistication of our neonatal life support system. In other words, viability measures medical technology, not one's humanity (37). Yet, one can take it as a measure of one's humanity, as it entails his accredited basic right to live. The mere presence of a chance for the fetus to survive after being severed from the support of the materno-fetal placenta - whether without or with sophisticated life support system - would influence the decision taken to assure safe exit from the intra-uterine environment. This decision involves the potential risks to the mother regarding the method of delivery, e.g. caesarean section. A basic Islamic concept is that the mother is the root and the fetus is the offshoot. If the two lives are at stake, the one that is certain and established, the mother, overrides the infant's life, which is still in some doubt. It is illogical to endanger the mother if there are certainly no chances for fetal survival, i.e. being not viable. Considering this, it is evidently clear that the humanity of the fetus is less than norm (his mother's) before the age of viability.

\section{Ensoulment}

Islam acknowledges some form of dualism, which is, recognizing that the body and soul subsist together and meet to form a »full human person « (10). The inspiration of the soul comes after 'sawwa' (fashioning man in due proportion) in many verses $(15: 39 ; 32: 9 ; 38: 72)$ (1, 2). Moreover, in Hadith after Ibn-Massoud, the Prophet Mohammad - pbuh - says: 'The creation of each one of you in his mother's abdomen is collected in forty days, then he becomes an 'alaqah' for the same (duration), then a 'mudghah' for the same. Then, Allah sends an angel, being ordered to write four things: his provision (sustenance), his age, his deeds and whether he will eventually be wretched or blessed. Then the soul (spirit) is breathed (blown) into him.' $(3,4)$. In another Hadith narrated by Huzaifa Ibn Osaid, the Prophet - pbuh - said: 'When 
the 'nutfah' enters the womb and stays there for forty nights, God sends an angel that gives it a form and creates its hearing, sight, skin, bone and flesh. Then the angel asks: O' God is it a male or a female? And God determines whatever He decides. He then asks what his livelihood is and God determines'(4). Both Hadiths are considered authentic according to the standards of the science of the Hadith $(3,4,12)$. The spirit or soul, however, is something that we, human beings, can not grasp or know the meaning of. All that man knows is that when it is breathed in, he gets the human life and when it departs, he is dead (16). It is a mystery that God kept the truth about to Himself, and we are told by God not to pursue the attempts to unravel its secret $(17: 85)(1,2)$. The blowing of the spirit is a metaphysical phenomenon beyond human comprehension at all times, and the Hadiths are taken as a matter of faith (12). Despite this conviction, old scholars had considered that the inspiration of the soul heralds the start of life, with an ongoing controversy. Based on the first Hadith, the majority of old scholars and jurists understood that each of the three stages - 'nutfah', 'alaqah' and 'mudghah' - lasts for 40 days; i.e. the total period being 120 days $(16,38)$. This view was reinforced by the coincidental occurrence of quickening by that time, despite the earlier presence of unperceived fetal movement (12). In accordance with the second Hadith, a second group declared that the whole period of formation for the three phases is forty days $(16,38)$. Prior to the breathing of soul, the type of life is to be considered a vegetative one devoid of volition. The human life starts when the soul is breathed unto the body, with both movements and perceptions becoming voluntary (16). According to the Grand Imam Shafiai, a conceptus is not to be considered an embryo before the end of 'alaqah' and 'mudghah' stages with identification of anything belonging to a human creature as a digit, a nail, an eye, or anything alike (38). In other words, these old scholars set the cut-off time at seven weeks of pregnancy, the assumed time of the visit of the angel reported in that Hadith. In addition, they maintained that it was the time when the organs have been already formed with the fetus shaped up to take a human form, i.e. a formed 'mudghah' $(12,16,38)$. However, the start of appearance of these things virtually occurs during 'mudghah' stage, with some of them being discerned very early such as the cardiovascular system, including the heart, being the first organ system to reach a functional state by the end of the third week (15).

Considering fetal rights, old scholars are agreed that after quickening takes place, abortion is prohibited to all Muslims, for it is a grave and punishable sin entailing a crime perpetrated against a living being. Therefore, a blood ransom is due if the fetus is delivered $(12,16,39)$ One notable exception - where therapeutic abortion is permissible - is a grave medical condition endangering the mother's life with further continuation of pregnancy $(12,16)$. Yet, some expresses concerns regarding assigning a case as therapeutic abortion, with current real dangers to mother's life, rather than prophylactic abortion, with variable degrees of presumptive danger (38). Juris- prudence considers that the mother is the root and the fetus is the offshoot, and if the welfare of both is irreconcilable then the fetus has to be sacrificed in order to save the mother. Though these medical indications have become quite rare in modern medical practice (12), termination of a pregnancy for a valid indication is virtually permissible throughout pregnancy. After ensoulment, the presence of a fine - blood ransom - in case of fetal damage signifies that the fetus acquires some basic human rights. The jurists were not, on the other hand, agreed whether to sanction or prohibit abortion if performed prior to the quickening phase. Some felt it was permissible on the grounds that no life existed and therefore no crime could be committed (39). Some of them set the cutoff point at 16 weeks $(12,16)$, which may be regarded suitable for the medical profession, as most of congenital abnormalities can be diagnosed ahead by ultrasound or amniocentesis $(16,18)$. A small minority considered abortion to be permissible only before the seventh week $(12,38)$. Commenting on this controversy, a contemporary jurist, Sheikh Shaltout concluded that the old scholars' differences of opinion on the permissibility of abortion resulted from their unawareness of the technical aspects of the question. This led them to regard abortion before, as different from abortion after, formation of the fetus is complete. It may be said therefore that they are all agreed on the interdiction of abortion at any time during pregnancy (40). So, consideration of ensoulment does not deprive the developing fetus before ensoulment from one basic right; that is the right to life, which human adults are entitled to. However, it may argued based on maslahah (benefit or interest) - that the use of surplus embryos from IVF, being not yet ensouled, in stem cell research has theological and philosophical reasoning rather than being left without medical intervention to end their life naturally (10).

\section{Implantation}

»Proclaim! (or Read!) In the name of thy Lord and Cherisher, Who created, * Created man ('Insan'), out of alaqahs " $(96: 2)(1,2)$. Overall in the Holy Qur'an, the verses state laws of creation; one of which is selection. It is well known that the formation of a zygote is not synonymous to the occurrence of a pregnancy. In human sense, we do not consider a woman to be pregnant after embryo transfer until there is an evidence of successful implantation (a positive pregnancy test). So, not every »alaqah« (zygote-blastocyst) develops into an embryo, a fact that has been termed by some investigators as natural selection (13). Considering human in vivo fertilization, it has been estimated that in any particular month $84 \%$ of the oocytes are fertilized, yet only $36 \%$ survive to 6 weeks, and approximately $31 \%$ are born alive at term (41). Others have found an overall pregnancy loss of $31 \%$ with $22 \%$ occurring before implantation. Although the number of pregnancies wasted before implantation is very large, most of them are not recognized clinically, and in practice the problem of early pregnancy loss is limited to those pregnancies aborted after implantation (35). Such 
unrecognized pregnancy wastage may be a way for discarding abnormal embryos $(15,19,42)$. In fact, failure of implantation is the primary factor causing failure to establish a pregnancy following IVF/ET therapy $(43,44)$. However, the failure rate of this procedure is not surprising as that of the natural fertilization process is quite similar $(15,19,35,42)$.

Another Holy verse states: »Allah knows what every female bears, and what do the wombs abate (drain) and what do they urge to increase. Every single thing with Him is in (due) proportion « $(13: 8)(1,2)$. Following formation of the zygote, a female does virtually bear or carry a potentially new creature (33). Failure of implantation is more likely to follow, with vanishing of the zygote (35, 42). As inspired from two verses $(20: 55$ and 30:20) $(1,2)$, mankind is virtually earth walking and scattering over earth. In the verse, the simile makes the womb similar to earth that swallows or drains the water that is subsequently abated. This matter happens around the clock, being unknown except for Allah; a fact that has been also expressed in Hadith 'None - expect Allah - knows what the wombs abate' (3). Alternatively, the womb (the earth) may express hospitality to this ensuing creature and urge it to increase more and more, i.e. divide and succeed in implantation. As already explained, this phase has been referred to as germination in the Holy Qur'an (71:17) (1, 2).

The mere presence of a zygote and the presence of a pregnancy in the female are not synonymous. In human sense, a woman is considered pregnant only if this zygote starts to implant itself, and present clear evidence of success in this respect, e.g. delayed menses or positive pregnancy test. As stated before, if a woman commits a crime the punishment of which is death and is proven to be pregnant, then the execution of the punishment shall be postponed until she gives birth to her baby and completes its breast feeding until weaned (12). This is not the case if there is no evidence of pregnancy yet, despite the possibility of presence of a zygote still attempting implantation. This implies that the human status of a zygote free in the uterine cavity is less than that of one already implanted.

\section{Fertilization \& Genetic Uniqueness}

The establishment of unique genetic code of any individual at fertilization is a fact that has been addressed in the Holy Qur'an in two verses: »Has there not been over man a period of time, when he was not a thing worth mentioning? * Verily We created man from a 'nutfah amshaj', in order to try him: So We gave him (the gifts), of hearing and sight « $(76: 1,2)(1,2)$. Allah, The Almighty, says, »Has there not been «Verily it comes, »over man «; the proposition »over « denoting that »a period of time« a variable period time has verily elapsed over man, as he was not present by himself, but his origin that can not be addressed nor categorized as man. These are the mother cells of the gametes; spermatogonia and primary oocyte before completion of meiosis. This thing is not »worth mentioning «, as it is undefined, and only after meiosis, just prior to gamete production, it becomes defined (or mentioned) with a unique genetic package for the rest of his life's period. Man is verily created »from a nutfah amshaj« is a subsequent developmental stage, the gametes and the zygote, the first phases exhibiting genetic uniqueness. "Amshaj is the pleural form of the noun 'mashij', literally meaning a thing resulting by mixture of two things only. "Amshaj « is used as an adjective for the singular noun »a nutfah«. Linguistically, this formulation implies that $» a$ nutfah (a droplet or a pearl) is nothing but a recollection of $» a m s h a j \ll ;$ i.e. a »nutafh « acts as a container for these »amshaj«. Scientifically, a 'mashij' denotes the unique recombinant chromosome formed after crossing-over of genetic material between homologous paternal chromosomes during meiosis. Both the gametes and the zygote are virtually $»$ nutfah amshaj«, i.e. a droplet or pearl that contains (or is nothing but) a group of unique recombinants »amshaj «, being 23 in the former and 46 in the latter. The main two mechanisms leading to genetic uniqueness entail mixing of pairs, the first is mixing of each two homologous chromosomes (crossing-over) during meiosis and the second is mixing of two gametes at fertilization. Both mechanisms have been precisely and comprehensively described in a single expression, »a nutfah amshaj«. Consequently, the zygote is virtually nothing but the end result product of two mixing processes (Figure 2). Hence, each human being is virtually the unique end-result of repetitive mixing of genetic matter up to Adam and Eve $(13,14)$.

An interesting question is posed; why the trying man is mentioned immediately following referral to genetic uniqueness? The effects of genetic makeup on the course of human life have been ever discovered to be overwhelming. In fact, we are the product of what we inherit and what is added from our environment. Does this verse refer to genetic uniqueness - taking place at fertilization - as to herald the start of a distinct human being - i.e. the start of a new life - to be tried? Al-Imam Al-Ghazali, the great master belonging to the Shafiai School, stated that the first grade of existence occurs when male 'nutfah' lies in the womb and mixes with the female water and gets ready for life (45). This has been recently elaborated in a view holding that the phase of life of an individual, qualifying to be considered its beginning, must fulfill certain criteria. It should be a well-defined point, with a unique genetic package, and exhibiting growth and if this growth is not interrupted, it will naturally lead up to the subsequent stages of life - fetus, neonate, child, etc. - as we know them. Moreover, it is not to be preceded by another phase that combines all the preceding characteristics. Applying these five criteria, life begins with the fusion of a spermatozoon with an ovum to form the zygote. Neither sperm nor unfertilized ovum fulfils the criteria although they are alive. Subsequent stages do not qualify because they are preceded by the zygote that fulfils all criteria (12). This concept holds for other many other groups, including the Catholic Church (32). Some biological obstacles to this definition are claimed. One is that this process is worked with an extreme surplus, en- 
tailing the need for several millions of sperms and disappearance of more than $70 \%$ of fertilized oocytes. Another relating one is that the cells of the blastocyst are totipotent that can result in abnormal trophoblastic tissue, such as a mole, which can not lay claim to being human life (32). Yet, these arguments do not hold as a fertilized oocyte has the potentiality to develop into a human being with relatively higher losses still occurring in the first trimester of pregnancy with gradual decrease as pregnancy advances (18).

In the Holy Qur'an, human creation is considered analogous to plant creation in many verses as has been already shown. Both entail the interaction between the seed or the 'alaqah' (zygote-blastocyst) and the soil or the uterine lining. The mere existence of seeds in the soil, with some being dormant for years, does not imply the presence of a life with the soil or earth being described as dead in many verses $(2: 164,16: 65,22: 5,29: 63,30: 19,24$, 50, 32:27, 35:9, 36:33, 41:39, 42:5, 57:17) (1, 2). The Holy Qur'an speaks of 'inbat' or germination. Life virtually begins when the interaction between the seed and soil starts i.e. germination or implantation. Both germination and implantation are ultimately according to Allah's Will, compared to sowing the seed when man's will may coincide. In biology, the term germination is applied to the resumption of the growth of the seed embryo after the period of dormancy. During it, water diffuses through the seed coats into the embryo - that has been almost completely dry during the period of dormancy - causing rehydration and swelling of the seed. Shortly thereafter, the rate of respiration increases, and various metabolic processes - suspended or much reduced during dormancy - resume. These events are associated with structural changes in the organelles in the cells of the embryo. The stored foodstuffs are broken down by enzymes into simpler substances that are transported through the embryo to make energy available for the various centers of growth. This is followed by emergence of the radicle or the primary root, the first portion of the embryo to break through the seed coat (22). So, germination virtually starts by embryonic development within the seed before interacting with the soil. By analogy, the changes occurring immediately after formation of the zygote - cleavage with subsequent development of the blastocyst $(15,19)-$ are actually a part of implantation process. In other words, the formation of the fertilized oocyte is the crucial event discerning the start of a human life as it heralds the start of the process of implantation.

\section{CONCLUSION}

Islam is a religion which has given great importance to what are known today as the ethical principles of autonomy, beneficence, non-maleficence, and justice. Reviewing old juridical writings, one feels that the prevailing concepts about the beginning of life were erroneous, and have been superceded by new facts which are amongst the fruits of advances not only in science and technology, but also in better meditation of the Holy verses. In Islam, human life is a value, and its sanctity covers all its stages starting from the moment of fertilization. This concurs with the old view of Al-Imam Al-Ghazali that life starts right at the beginning and abortion being unlawful once male 'nutfah' lies in the womb and mixes with the female water and gets ready for life, maintaining that it already had invisible life, that of growth and preparation. So, to destroy this is a crime. The crime grows more and more serious as this matter passes from one phase to the other. The crime is more heinous after the blowing of the spirit, and reaches its worst after the baby is born alive as was the pre-Islamic (Jahiliya) Arabs' practice of killing or burying their female neonates (45). This escalation in the degree of crime, acknowledged by some investigators as moral distancing (30), differs from the Catholic Church's view that sees the resultant human zygote as equivalent to an existing and actual person integrated to the full realization of his or her personhood (32). Some investigators considers that, as far as biology is concerned, there is no point along the life continuum - from fertilization to death - at which the individual becomes or is made a »man« and there is no point at which the individual ceases to be a »man«. It is considered illogical to create a sliding scale to measure »humanity-gained « for a process that is a biological continuum (46). In fact, this scale exists - as already discussed - to measure human rights gained in comparison to others' well-established human rights. Although this escalation clarifies the absence of full human rights of a developing fetus till being viable and born alive, it does not negate one basic right, »the right to life«, i.e. to be protected as a potential human being with eventual full human rights. As shown here, the close matching between Qur'an, the word of Allah, and science, the deeds of Allah, poses no major conflicts in defining the start of human life. The consensus is that from the moment a zygote is formed, it deserves a unanimously recognized degree of respect. The later occurrence of ensoulment should not be taken as a prelude to justify unaccepted tampering with on a man-to-be developing zygote.

\section{REFERENCES}

1. The Holy Qur'an

2. Translation of The Holy Qur'an and Its Meaning: (a) Ali, Abdullah Yusuf: The Holy Qur'an. Text, Translation and Commentary. Amana Corporation, Maryland, USA, 1409 AH/1989 AC. (b) Al-Hilâli, Muhammed Taqi-udDin and Khan, Muhammed Muhsin: Translation of the meaning of the Noble Qur'an. King Fahd Complex for the Printing of the Holy Qur'an, Madinah, KSA, 1997. (c) Author's views (in italics) including translation and transliteration (underlined).

3. Al-Jami' Al-Saheeh: by Abu Abdullah Mohammed Ibn Ismail Al-Ja'fi Al-Bukhari.

4. Saheeh Moslem: by Abu Al-Hussein MoslIbn Al-Hajaj Al-Qushairi Al-Nissaboori.

5. Musnad Ahmad: by Abu Abdulla Ahmad Ibn Mohammad Ibn Hanbal.

6. Al-Jami' Li'Ahkam Al-Qur'an: by Abu Abdullah Mohammed Ibn Ahmad Al-Qurtubi.

7. Tafseer Al-Fakhr Al-Razi, widely known as Al-Tafsser Al-Kabeer: by Abu Abdullah Mohammad Ibn Omar Ibn Hussein Al-Qurashi.

8. Tafseer El-Maraghy: by Ahmed Mostafa Al-Maraghy, Mostafa Paby Al-Halaby \& Sons Pub., Cairo, Egypt. 
9. SEROUR G I 1998 Reproductive Choice: A Muslim Perspective. In The Future of Human Reproduction: Ethics, Choice and Regulation edited by John Harris and Soren Holm. Clarendon Press, p 191-202.

10. AKSOY S 2005 Making regulations and drawing up legislation in Islamic countries under conditions of uncertainty, with special reference to embryonic stem cell research. J Med Ethics 31: 399-403.

11. KHAYAT H 2006 Research ethics: challenges in the Eastern Mediterranean Region. Eastern Mediterranean Health Journal 12 (Supplement 1): S13-S20.

12. HATHOUT H 1988 Islamic Perspectives in Obstetrics and Gynaecology, Rotaprint, Kuwait, 23-26, 32-39, 63-78, 99, 125-137.

13. ABD-EL-MAEBOUD K H I 2000 Dawret Hayat Al-Insan bina Al-Ilem wa Al-Qur'an (Human Life Cycle: Science and Holy Qur'an, Arabic). Nahdet Miser, Cairo, Egypt, First Edition, 2000AC.

14. ABD-EL-MAEBOUD K H I, KURJAK A, CULEJ J B 2000 The Embryo: An Islamic Perspective. Gynaecol Perinatol 9(4): 133-137.

15. MOORE K L 1983 The Developing Human: Clinically Oriented Embryology, with Islamic Additions: Correlation Studies with Qur'an and Hadith by Azzindani, A-M A., Dar Al-Qiblah, Jeddah, Saudi Arabia, p 1-95, 100, 101-103, 221-223, 255-297, 336, 344-374, 413-431, 14a, 20a, 30a, 32a, 34a, 40a, 56a, 80a, 86a, 86b, 86c, 100a, 100b, 158a, 272a, 272b, 336b, 364a, 446a-446g, 458a-458s.

16. AL-BAR M A 1989 Human Development as Revealed in the Holy Quran and Hadith: By Dr., Saudi Publishing \& Distributing House, Jeddah, KSA, $2^{\text {nd }}$ Edition, p 11-16, 51-94, 107-147.

17. AL-BAR M A 1981 Khalq Al-Insan Baen Al-Teb wa Al-Qur'an (Human Creation: Medicine and Holy Qur'an, Arabic). Saudi Publishing \& Distributing House, Jeddah, S.A., Third Edition, $1402 \mathrm{AH}$, p 23-26, 109-157, 183-194, 201-231, 243-250, 277-308, 365-382, $421-430$.

18. CUNNINGHAM F G, MACDONALD P C, GANT N F 1989 Williams Obstetrics. Appleton \& Lange, Norwalk, Connecticut, USA, $18^{\text {th }}$ edition, p 40-61, 103, 118, 257-259, 489, 572-575, 582-589, 741-748, 887-914.

19. SADLER T W 1993 Langman's Medical Embryology. William \& Wilkins, Baltimore, USA, 1990, $6^{\text {th }}$ Edition. Egyptian Edition by Mass Pub. Co., Cairo, Egypt, p 3-84, 139-163, 260-296, 328-346.

20. QUINN P, WARNES G M, KERIN J H \& KIRBY C 1984 Culture factors in relation to the success of human in vitro fertilization and embryo transfer. Fertility $\mathcal{E}$ Sterility 41(2): 202-209.

21. Abu Al-Fadl Hamaluddin Mohammad Ibn Makram Ibn Manzoor Al-Afriki Al-Masri (630-711AH): Lisan Al-Arab (Arabian Tongue, Arabic Language Dictionary). Dar Sader, Beirut, Lebanon, $1^{\text {st }}$ Edition, 1410AH-1990AC.

22. Encyclopedia Britannica 98 CD: Published by Encyclopedia Britannica Inc., Chicago, USA, 1998.

23. HENSYL W R et al. 1982 Illustrated Stedman's medical dictionary. Williams \& Wilkins, Baltimore, USA, 24 ${ }^{\text {th }}$ edition, p 610, 697.

24. BOVING G B, LARSEN J F 1980 Implantation. In: Hafez E S E (ed) Human reproduction: conception and contraception. Harper \& Row, Hagerstown, Maryland, USA, chap.21, p 471-487.

25. ARMANT D R, DIAZ D 1990 Embryo-uterine interactions during implantation. In: Seibel M M (ed) Infertility: A comprehensive Text. Appleton \& Lange, Norwalk, Connecticut, USA, chap 33, p 457-470.

26. FINDLAY J K 1984 Implantation and early pregnancy. In: Trounson $\mathrm{A} \&$ Wood $\mathrm{C}(e d s)$ In vitro fertilization and embryo transfer. Churchill Livingstone, Edinburgh, GB, chap. 5, p 57-72.

27. FINN C A 1977 The implantation reaction. In: Wynn R M (ed) Biology of the uterus. Plenum Press, New York, USA, $2^{\text {nd }}$ edition, chap.9, p 245-308.
28. CLARK D A 1994 Endometrial Molecular and Cellular Determinants of Fertility. In: Behrman S J, Patton G W, Holz G (eds) 1994 Progress in Infertility. Little, Brown and Company (Inc.), Boston, USA, $4^{\text {th }}$ Edition, chap. 2, p 37-44.

29. ABD-EL-MAEBOUD K H I, KURJAK A, CULEJ J B $2001 \mathrm{Hu}$ man Life Cycle: An Islamic Perspective. Gynaecol Perinatol 10(1): 31-34.

30. BIGGERS J D Ethical Considerations in Infertility: Human Generation - Fact, Foible, and Fable. In: Seibel M M (ed) Infertility: A Comprehensive Text. Appleton \& Lange, Norwalk, Connecticut, USA, 1990, Chap. 39, p 551-562.

31. DUNSTAN G R 1995 Pre-embryo research. J Assist Reprod Genet 12(1): 517-523.

32. BELLER F K, ZLANTIK G P 1995 The beginning of human life.J Assist Repod Genet 12(8): 477-483.

33. ABD-EL-MAEBOUD K H I 2000 The Age of Viability: an Islamic perspective. In: Cosmi E V (ed). The Proceedings of the $16^{\text {th }}$ International Conference »The Fetus as a Patient«, Fiuggi (Rome), Italy, April 2-5, 2000. Monduzzi Editore, Bologna, Italy, p 241-248.

34. HALLIDAY H L 1992 Prematuriy. In: Calder A A \& Dunlop W (eds) High-risk Pregnancy, Butterworth-Heinemann, Oxford, GB, First Edition, 1992, Chap. 10, p 332-361.

35. ARIAS F 1993 Practical Guide to High-risk Pregnancy and Delivery Mosby Year Book, St. Louis, US, $2^{\text {nd }}$ Edition, p 55, 71-99.

36. BEHRMAN R E, KLIEGMAN R M, NELSON W E, \& VAUGHAN V C 1992 Nelson Textbook of Pediatrics. W.B. Saunders Co., Philadelphia, US, 14th Edition, p 14, 15, 18.

37. KURJAK A, BULJAN J 2000 When does human life begin? In: Cosmi E V (ed) The Proceedings of the $16^{\text {th }}$ International Conference »The Fetus as a Patient«, Fiuggi (Rome), Italy, April 2-5. Monduzzi Editore, Bologna, Italy, p 249-259.

38. AL-BOOTY M S R 1976 Masalat Tahdid Annasel, Wiqaiah wa Ielag (The question of conception control: prophylaxis and treatment, Arabic). Maktabat Al-Faraby, Damascus, Syria, $2^{\text {nd }}$ edition, p 65-131, 177-214.

39. Shaltout: Al-Islam: Al-Aqidah wa al-Shariah (Islam- Creed and Law, Arabic). Dar alQalam pub., $3^{\text {rd }}$ Edition, 1966.

40. Shaltout: Al-Fatawa-AI-Azhar, 1959. Quoted from 12.

41. STENCHEVER M A, JONES H W 1987 Genetic disorders and sex chromosome abnormalities. In: Pernoll M L, Benson R C (eds) Current Obstetric \& Gynecology: Diagnosis \& Treatment. Appleton \& Lange, Norwalk, US, $6^{\text {th }}$ Edition, 1987, chap. 3, p 79-108.

42. SHORT R V 1979 »When a conception fails to become a pregnancy«. Ciba Foundation Symposium 64, Maternal recognition of pregnancy. Excerpta Medica, Amsterdam, p 377-394.

43. EDWARDS R G, STEPTOE P C, PURDY J M 1980 Establishing full term human pregnancies using cleaving embryos grown in vitro. Br J Obstet Gyn 87: 737.

44. LAUFER N, GRUNFELD L, GARRISI G J 1990 In Vitro Fertilization. In: Seibel M M (ed) Infertility, A Comprehensive Text, Appleton \& Lange, Norwalk, Connecticut, US, chap. 35, p 481-511.

45. Al-Imam Al-Ghazali: Ihia Iloum Al-Deen (Revival of religious sciences, Arabic). Quoted from 38.

46. SCARPELLI E M, COSMI E V 2000 When does human life begin? In: Cosmi E V (ed) The Proceedings of the $16^{\text {th }}$ International Conference »The Fetus as a Patient«, Fiuggi (Rome), Italy, April 2-5. Monduzzi Editore, Bologna, Italy, p 235-239. 